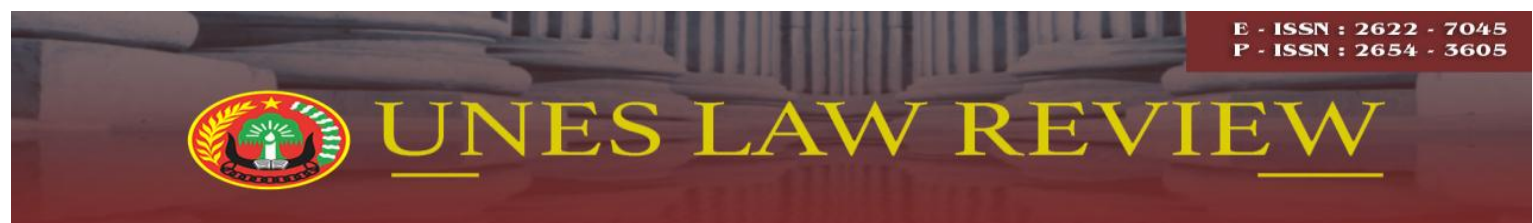

Email: uneslawreview@gmail.com

Online: http://review-unes.com/index.php/law

Volume 2, Issue 3, Maret 2020

\title{
PERKEMBANGAN PERBANKAN SYARIAH DI INDONESIA
}

\author{
Andrew Shandy Utama \\ Prodi Ilmu Hukum Fakultas Hukum, Universitas Lancang Kuning, Indonesia \\ Email: andrew.fh.unilak@gmail.com
}

\begin{abstract}
ABSTRAK
Bank syariah adalah bank yang menjalankan kegiatan usahanya berdasarkan prinsipprinsip hukum Islam dalam kegiatan perbankan berdasarkan fatwa yang dikeluarkan oleh Dewan Syariah Nasional Majelis Ulama Indonesia. Penelitian ini bertujuan untuk menjelaskan perkembangan perbankan syariah di Indonesia. Metode yang digunakan dalam penelitian ini adalah penelitian hukum normatif dengan menggunakan pendekatan peraturan perundang-undangan. Hasil dari penelitian ini adalah bahwa prakarsa mengenai pendirian bank syariah di Indonesia mulai dilakukan sejak tahun 1990 oleh Majelis Ulama Indonesia, yang diwujudkan dengan berdirinya Bank Muamalat Indonesia pada tanggal 1 November 1991. Perkembangan awal perbankan syariah dalam sistem perbankan nasional direspon dengan cepat oleh pemerintah dengan disahkannya Undang-Undang Nomor 7 Tahun 1992 tentang Perbankan, yang kemudian diubah dengan Undang-Undang Nomor 10 Tahun 1998. Selain menjadi kehancuran bagi sistem perbankan nasional, krisis ekonomi yang terjadi tahun 1998 juga menjadi titik tolak perkembangan perbankan syariah di Indonesia. Beberapa bank konvensional mulai mengembangkan usahanya dengan mendirikan bank syariah. Merespon perkembangan perbankan syariah yang signifikan dalam sistem perbankan nasional, maka pada tanggal 16 Juli 2008 disahkan UndangUndang Nomor 21 Tahun 2008 tentang Perbankan Syariah sebagai landasan hukum tersendiri bagi bank syariah di Indonesia.
\end{abstract}

Kata Kunci: Hukum, Perbankan Syariah, Perkembangan

\section{PENDAHULUAN}

Sebagaimana yang diamanatkan oleh Pancasila dan Undang-Undang Dasar Negara Republik Indonesia Tahun 1945, tujuan pembangunan nasional adalah terciptanya masyarakat adil dan makmur berdasarkan demokrasi ekonomi dengan mengembangkan sistem ekonomi yang berkeadilan. Untuk menjamin berlangsungnya demokrasi ekonomi, maka segala potensi, inisiatif, dan daya kreasi rakyat wajib dimobilisasikan dan dikembangkan sepenuhnya dalam batas-batas yang tidak merugikan kepentingan umum, sehingga dengan demikian, segala kekuatan ekonomi potensial dapat dikerahkan menjadi kekuatan ekonomi yang nyata bagi kemanfaatan peningkatan kemakmuran rakyat. Guna mencapai tujuan tersebut, maka pelaksanaan pembangunan ekonomi harus lebih 
memperhatikan keselarasan, keserasian, dan keseimbangan unsur-unsur pemerataan pembangunan, pertumbuhan ekonomi, dan stabilitas nasional. Salah satu lembaga yang mempunyai peran strategis dalam menyerasikan, menyelaraskan, dan menyeimbangkan masing-masing unsur dari trilogi pembangunan tersebut adalah perbankan.

Perbankan adalah segala sesuatu yang menyangkut tentang bank, mencakup kelembagaan, kegiatan usaha, serta cara dan proses dalam melaksanakan kegiatan usahanya. Secara sederhara, bank diartikan sebagai lembaga keuangan yang kegiatan usahanya adalah menghimpun dana dari masyarakat dan menyalurkan kembali dana tersebut ke masyarakat, serta memberikan jasa-jasa keuangan lainnya (Kasmir, 2012: 3).

Menurut kegiatan usahanya, jenis-jenis bank dapat dibedakan atas bank konvensional dan bank syariah (Djoni S. Gazali dan Rachmadi Usman, 2012: 151). Bank konvensional adalah bank yang menjalankan kegiatan usahanya secara konvensional, sedangkan bank syariah adalah bank yang menjalankan kegiatan usahanya berdasarkan prinsip-prinsip hukum Islam dalam kegiatan perbankan berdasarkan fatwa yang dikeluarkan oleh Dewan Syariah Nasional Majelis Ulama Indonesia (Andrew Shandy Utama, 2018: 38).

Prakarsa mengenai pendirian bank syariah di Indonesia baru dimulai tahun 1990 oleh Majelis Ulama Indonesia dan bank syariah yang pertama berdiri di Indonesia adalah Bank Muamalat Indonesia tahun 1991. Berdasarkan data Otoritas Jasa Keuangan pada tahun 2017, saat ini bank umum syariah di Indonesia berjumlah 13 bank, unit usaha syariah dari bank umum konvensional berjumlah 21 bank, dan Bank Pembiayaan Rakyat Syariah berjumlah 102 bank.

Dari pendahuluan yang telah diuraikan di atas, maka permasalahan yang dibahas dalam penelitian ini adalah bagaimanakah perkembangan perbankan syariah di Indonesia?

\section{METODE PENELITIAN}

Penelitian hukum adalah suatu kegiatan ilmiah yang didasarkan pada metode, sistematika, dan pemikiran tertentu yang bertujuan untuk mempelajari satu atau beberapa gejala hukum tertentu dengan jalan menganalisanya (Soerjono Soekanto, 2007). Metode yang digunakan dalam penelitian ini adalah penelitian hukum normatif, dengan menggunakan pendekatan peraturan perundang-undangan. Penelitian hukum normatif adalah suatu proses untuk menemukan aturan hukum, prinsip-prinsip hukum, maupun 
doktrin-doktrin hukum guna menjawab isu-isu hukum yang dihadapi (Peter Mahmud Marzuki, 2011). Sumber data yang digunakan dalam penelitian ini adalah data sekunder, yaitu data yang diperoleh dari peraturan perundang-undangan, jurnal-jurnal ilmiah, dan literatur hukum. Teknik pengumpulan data yang digunakan dalam penelitian ini adalah studi kepustakaan. Teknik analisis data yang digunakan dalam penelitian ini adalah analisis kualitatif.

\section{HASIL PENELITIAN DAN PEMBAHASAN}

Bank syariah adalah bank yang menjalankan kegiatan usahanya berdasarkan prinsip-prinsip hukum Islam dalam kegiatan perbankan berdasarkan fatwa yang dikeluarkan oleh Dewan Syariah Nasional Majelis Ulama Indonesia (Andrew Shandy Utama, 2018: 38). Sejarah perbankan syariah pertama kali adalah pendirian sebuah bank Islam di Mesir, yaitu didirikannya Islamic Rural Bank di Kairo pada tahun 1963. Bank Islam pertama yang dimiliki oleh pihak swasta adalah Dubai Islamic Bank, yang didirikan pada tahun 1975 oleh sekelompok pengusaha muslim yang berasal dari berbagai negara (Abdul Ghofur Anshori, 2009: 25-26).

Perkembangan perbankan syariah secara internasional dimulai dengan adanya Sidang Menteri Luar Negeri yang diselenggarakan oleh Organisasi Konferensi Islam di Pakistan pada Desember 1970. Mesir mengajukan proposal pendirian International Islamic Bank for Trade and Development dan proposal pendirian Federation of Islamic Banks. Setelah mendapatkan pembahasan dari 18 negara Islam, akhirnya proposal tersebut diterima. Pada tahun 1975, Sidang Menteri Keuangan yang diselenggarakan oleh Organisasi Konferensi Islam di Arab Saudi menyetujui pendirian Islamic Development Bank (Abdul Ghofur Anshori, 2009: 26). Menurut Organization of the Islamic Conference, bank Islam adalah institusi keuangan yang memiliki hukum, aturan, dan prosedur sebagai wujud dari komitmen kepada prinsip syariah serta melarang menerima dan membayar bunga dalam proses operasional yang dijalankan (Veithzal Rivai dan Arviyan Arifin, 2010: 31).

Sudah cukup lama umat Islam, termasuk di Indonesia, mengalami berbagai kendala dalam pengembangan potensi dan pembangunan ekonominya. Salah satu penyebabnya adalah penyakit dualisme antara ekonomi dan syariah yang cukup kronis. Dualisme ini 
muncul sebagai akibat dari ketidakmampuan umat untuk menggabungkan dua disiplin ilmu, ekonomi dan syariah, yang seharusnya saling mengisi dan menyempurnakan (Muhammad Syafi'i Antonio, 2002: 17).

Di Indonesia, sebagaimana diamanatkan oleh Pancasila dan Undang-Undang Dasar Negara Republik Indonesia Tahun 1945, tujuan pembangunan nasional adalah terciptanya masyarakat adil dan makmur berdasarkan demokrasi ekonomi dengan mengembangkan sistem ekonomi yang bertumpu pada mekanisme pasar yang berkeadilan. Guna mewujudkan tujuan tersebut, pelaksanaan pembangunan ekonomi nasional diarahkan pada perekonomian yang berpihak pada ekonomi kerakyatan, merata, mandiri, handal, berkeadilan, dan mampu bersaing di kancah perekonomian internasional. Agar tercapai tujuan pembangunan nasional dan dapat berperan aktif dalam persaingan global yang sehat, diperlukan partisipasi dan kontribusi semua elemen masyarakat untuk menggali berbagai potensi yang ada di masyarakat guna mendukung proses akselerasi ekonomi dalam upaya merealisasikan tujuan pembangunan nasional.

Salah satu bentuk penggalian potensi dan wujud kontribusi masyarakat dalam perekonomian nasional tersebut adalah pengembangan sistem ekonomi berdasarkan nilainilai Islam (syariah) dengan mengangkat prinsip-prinsipnya ke dalam sistem hukum nasional. Prinsip syariah berlandaskan pada nilai-nilai keadilan, kemanfaatan, keseimbangan, dan keuniversalan. Nilai-nilai tersebut diterapkan dalam pengaturan perbankan yang didasarkan pada prinsip syariah, yang disebut sebagai perbankan syariah.

Prakarsa mengenai pendirian bank syariah di Indonesia mulai dilakukan tahun 1990. Pada tanggal 18-20 Agustus 1990, Majelis Ulama Indonesia menyelenggarakan 'Lokakarya Bunga Bank dan Perbankan' di Bogor, Jawa Barat. Hasil lokakarya tersebut kemudian dibahas lebih mendalam pada Musyawarah Nasional ke-IV Majelis Ulama Indonesia di Jakarta pada tanggal 22-25 Agustus 1990 untuk membentuk tim kerja pendirian bank Islam di Indonesia. Hasil kerja tim tersebut adalah berdirinya Bank Muamalat Indonesia pada tanggal 1 November 1991, yang resmi beroperasi pada tanggal 1 Mei 1992 (Rachmadi Usman, 2012: 71). Setelah itu, maka berdirilah beberapa Bank Perkreditan Rakyat Syariah, yaitu Bank Perkreditan Rakyat Syariah Berkah Amal Sejahtera, Bank Perkreditan Rakyat Syariah Dana Mardhatillah, dan Bank Perkreditan 
Rakyat Syariah Amanah Rabaniah di Bandung, serta Bank Perkreditan Rakyat Syariah Hareukat di Aceh.

Perkembangan awal perbankan syariah dalam sistem perbankan nasional direspon dengan cepat oleh pemerintah. Pada tanggal 25 Maret 1992, disahkan Undang-Undang Nomor 7 Tahun 1992 tentang Perbankan menggantikan Undang-Undang Nomor 14 Tahun 1967 tentang Pokok-pokok Perbankan guna mengakomodir berdirinya bank syariah di Indonesia.

Pada Pasal 6 Huruf m dan Pasal 13 Huruf c Undang-Undang Nomor 7 Tahun 1992 disebutkan bahwa usaha bank umum dan Bank Perkreditan Rakyat salah satunya adalah menyediakan pembiayaan bagi nasabah berdasarkan prinsip bagi hasil sesuai dengan ketentuan yang ditetapkan dalam peraturan pemerintah. Ketentuan ini menjadi dasar hukum bagi perbankan syariah dalam menjalankan kegiatan usahanya. Ketentuan ini lalu diperkuat dengan disahkannya Peraturan Pemerintah Nomor 72 Tahun 1992 tentang Bank Berdasarkan Prinsip Bagi Hasil.

Lahirnya Undang-Undang Nomor 10 Tahun 1998 sebagai perubahan atas UndangUndang Nomor 7 Tahun 1992 semakin menguatkan regulasi mengenai perbankan syariah di Indonesia. Pada Pasal 1 Undang-Undang Nomor 10 Tahun 1998 disebutkan secara jelas bahwa bank umum maupun Bank Perkreditan Rakyat adalah bank yang melaksanakan kegiatan usaha secara konvensional dan/atau berdasarkan prinsip syariah. Pada pasal tersebut juga dijelaskan pengertian mengenai prinsip syariah, yaitu aturan perjanjian berdasarkan hukum Islam antara bank dan pihak lain untuk penyimpanan dana dan/atau pembiayaan kegiatan usaha, atau kegiatan lainnya yang dinyatakan sesuai dengan syariah, antara lain pembiayaan berdasarkan prinsip bagi hasil (mudharabah), pembiayaan berdasarkan prinsip penyertaan modal (musharakah), prinsip jual beli barang dengan memperoleh keuntungan (murabahah), serta pembiayaan barang modal berdasarkan prinsip sewa murni tanpa pilihan (ijarah) atau dengan adanya pilihan pemindahan kepemilikan atas barang yang disewa dari pihak bank oleh pihak lain (ijarah wa iqtina).

Masyarakat Indonesia pernah kehilangan kepercayaan terhadap dunia perbankan pada saat terjadinya krisis ekonomi tahun 1998. Krisis ekonomi tersebut menjadi kehancuran bagi sistem perbankan nasional (Andrew Shandy Utama, 2018: 6). Akan tetapi, ternyata bank syariah tidak terkena dampak dari krisis ekonomi yang terjadi tahun 1998. 
Pada saat krisis ekonomi berlangsung, secara faktual Bank Muamalat Indonesia yang merupakan satu-satunya bank umum syariah yang ada di Indonesia termasuk dalam kategori bank yang sehat karena mempunyai Capital Adequacy Ratio dengan kategori 'A' Artinya, bank syariah ternyata dapat menunjukkan kinerja yang relatif lebih baik dibandingkan dengan bank-bank konvensional (Abdul Ghofur Anshori, 2009: 4-5).

Selain menjadi kehancuran bagi sistem perbankan nasional, krisis ekonomi yang terjadi tahun 1998 juga menjadi titik tolak perkembangan perbankan syariah di Indonesia. Hal ini dikarenakan bank syariah tidak terkena dampak dari krisis ekonomi tersebut. Beberapa bank konvensional, baik bank milik pemerintah maupun swasta, yang mengembangkan usahanya dengan mendirikan bank syariah, seperti Bank Syariah Mandiri yang didirikan tahun 1999, Bank Permata Syariah yang didirikan tahun 2002, Bank Mega Syariah yang didirikan tahun 2004, Bank Rakyat Indonesia Syariah yang didirikan tahun 2008, Bank Syariah Bukopin yang didirikan tahun 2008, dan lain sebagainya (Andrew Shandy Utama, 2018: 108-109). Merespon perkembangan perbankan syariah yang signifikan dalam sistem perbankan nasional, maka pada tanggal 16 Juli 2008 disahkan Undang-Undang Nomor 21 Tahun 2008 tentang Perbankan Syariah sebagai landasan hukum tersendiri bagi bank syariah di Indonesia.

Undang-Undang Perbankan Syariah Nomor 21 Tahun 2008 secara filosofi yuridis telah memenuhi tuntutan rasa keadilan dan kepastian hukum pencari keadilan, terutama menyangkut transaksi bisnis ekonomi syariah (M. Ali Mansyur, 2011: 74). Perkembangan perbankan syariah di Indonesia berlangsung dengan cepat. Semua itu tidak bisa lepas dari eksistensi Bank Muamalat Indonesia (Mohamad Nur Yasin, 2010: 10).

Berdasarkan data Otoritas Jasa Keuangan pada tahun 2017, saat ini bank umum syariah di Indonesia berjumlah 13 bank, unit usaha syariah dari bank konvensional berjumlah 21 bank, dan Bank Pembiayaan Rakyat Syariah berjumlah 102 bank. Inilah bukti eksistensi dan perkembangan perbankan syariah yang signifikan dalam sistem perbankan nasional. Artinya, bank syariah merupakan lembaga keuangan yang dapat berkembang dengan pesat atas dasar kepercayaan dari masyarakat Indonesia yang mayoritas beragama Islam.

Masyarakat Indonesia percaya kepada perbankan syariah karena selain memiliki tanggung jawab hukum terhadap peraturan perundang-undangan, bank syariah juga 
memiliki tanggung jawab moral terhadap masyarakat dan tanggung jawab ibadah kepada Allah. Bank syariah memiliki tanggung jawab moral terhadap masyarakat artinya bahwa masyarakat menganggap orang yang bekerja di bank syariah mempunyai akhlak yang baik sesuai dengan ajaran Islam, misalnya jujur dalam bekerja. Bank syariah memiliki tanggung jawab ibadah kepada Allah artinya bahwa orang yang bekerja di bank syariah secara tidak langsung telah berdakwah menjalankan syari'at Islam di bidang muamalah, misalnya menganjurkan masyarakat untuk meninggalkan riba.

Perbedaan antara bank konvensional dan bank syariah yaitu adanya pengawasan khusus pada bank syariah yang dilakukan oleh Dewan Syariah Nasional Majelis Ulama Indonesia (MUI) secara umum dan Dewan Pengawas Syariah secara khusus. Dewan Syariah Nasional Majelis Ulama Indonesia (MUI) bertugas menumbuhkembangkan penerapan nilai-nilai syariah dalam kegiatan perekonomian pada umumnya dan keuangan pada khususnya, mengeluarkan fatwa atas jenis-jenis kegiatan keuangan, mengeluarkan fatwa atas produk dan jasa keuangan syariah, serta mengawasi penerapan fatwa yang telah dikeluarkan (Hasnati, Sandra Dewi, dan Andrew Shandy Utama, 2019: 206).

Dewan Pengawas Syariah bertugas mengawasi proses pengembangan produk baru bank syariah, meminta fatwa kepada Dewan Syariah Nasional Majelis Ulama Indonesia (MUI) untuk produk baru bank syariah yang belum ada fatwanya, melakukan review secara berkala terhadap mekanisme penghimpunan dana dan penyaluran dana serta pelayanan jasa bank syariah, serta meminta data dan informasi terkait dengan aspek syariah dari satuan kerja bank syariah dalam rangka pelaksanan tugasnya (Abdul Ghofur Anshori, 2009: 50).

Perkembangan bank syariah di Indonesia dewasa ini berjalan dengan sangat pesat. Walaupun demikian, jumlah bank, jumlah kantor bank, dan jumlah total aset bank syariah masih sangat kecil apabila dibandingkan dengan bank konvensional. Berdasarkan data Otoritas Jasa Keuangan pada tahun 2018, jumlah nasabah yang menyimpan dana di bank syariah hanya berjumlah 23,1 juta orang dan nasabah yang meminjam dana di bank syariah hanya berjumlah 4,7 juta orang. Jumlah ini tentunya masih sangat sedikit jika dibandingkan dengan jumlah penduduk Indonesia yang beragama Islam, yang jumlahnya mencapai 207,1 juta jiwa menurut data sensus penduduk tahun 2010. 


\section{PENUTUP}

Bank syariah adalah bank yang menjalankan kegiatan usahanya berdasarkan prinsip-prinsip hukum Islam dalam kegiatan perbankan berdasarkan fatwa yang dikeluarkan oleh Dewan Syariah Nasional Majelis Ulama Indonesia. Prakarsa mengenai pendirian bank syariah di Indonesia mulai dilakukan sejak tahun 1990 oleh Majelis Ulama Indonesia, yang diwujudkan dengan berdirinya Bank Muamalat Indonesia pada tanggal 1 November 1991. Perkembangan awal perbankan syariah dalam sistem perbankan nasional direspon dengan cepat oleh pemerintah dengan disahkannya Undang-Undang Nomor 7 Tahun 1992 tentang Perbankan, yang kemudian diubah dengan Undang-Undang Nomor 10 Tahun 1998. Selain menjadi kehancuran bagi sistem perbankan nasional, krisis ekonomi yang terjadi tahun 1998 juga menjadi titik tolak perkembangan perbankan syariah di Indonesia. Beberapa bank konvensional mulai mengembangkan usahanya dengan mendirikan bank syariah. Merespon perkembangan perbankan syariah yang signifikan dalam sistem perbankan nasional, maka pada tanggal 16 Juli 2008 disahkan UndangUndang Nomor 21 Tahun 2008 tentang Perbankan Syariah.

\section{DAFTAR PUSTAKA}

\section{Buku Taks:}

Abdul Ghofur Anshori. Perbankan Syariah di Indonesia. Yogyakarta: Gadjah Mada University Press, 2009.

Djoni S. Gazali dan Rachmadi Usman. Hukum Perbankan. Jakarta: Sinar Grafika, 2012.

Kasmir. Dasar-dasar Perbankan. Jakarta: Rajawali Pers, 2012.

Peter Mahmud Marzuki. Penelitian Hukum. Jakarta: Kencana, 2011.

Rachmadi Usman. Aspek Hukum Perbankan Syariah di Indonesia. Jakarta: Sinar Grafika, 2012.

Peter Mahmud Marzuki. Penelitian Hukum. Jakarta: Kencana, 2011.

Soerjono Seokanto. Pengantar Penelitian Hukum. Jakarta: UI Press, 2007.

Veithzal Rivai dan Arviyan Arifin. Islamic Banking. Jakarta: Bumi Aksara, 2010.

\section{Hasil Penelitian \& Journal:}

Andrew Shandy Utama. 2018. "Independensi Pengawasan terhadap Bank Badan Usaha Milik Negara (BUMN) dalam Sistem Hukum Nasional di Indonesia”. Jurnal Soumatera Law Review, Vol. 1, No. 1, Hal. 1-21. 
Andrew Shandy Utama. 2018. "History and Development of Islamic Banking Regulations in the National Legal System of Indonesia”. Jurnal Al-'Adalah, Vol. 15, No. 1, Hal. 37-50.

Andrew Shandy Utama. 2018. "Sejarah dan Perkembangan Regulasi Mengenai Perbankan Syariah dalam Sistem Hukum Nasional di Indonesia". Jurnal Wawasan Yuridika, Vol. 2, No. 2, Hal. 100-113.

Hasnati, Sandra Dewi, dan Andrew Shandy Utama. 2019. "Perbandingan Prinsip Good Corporate Governance pada Bank Konvensional dan Bank Syariah dalam Sistem Hukum di Indonesia”. Jurnal Mizan, Vol. 3, No. 2, Hal. 197-207.

M. Ali Mansyur. 2011. "Aspek Hukum Perbankan Syariah dan Implementasinya di Indonesia”. Jurnal Dinamika Hukum, Vol. 11, Ed. Khusus, Hal. 67-75.

Mohamad Nur Yasin. 2010. "Argumen-argumen Kemunculan Awal Perbankan Syariah di Indonesia". Jurnal De Jure, Vol. 2, No. 1, Hal. 109-123.

Muhammad Syafi'i Antonio. 2012. "Bisnis dan Perbankan dalam Perspektif Hukum Islam”. Jurnal Al Mawarid, Ed. VII, Hal. 17-25. 